\title{
都市中小河川・下水道の連携した治水計画 一台地部既成市街地を対象としてー
}

\author{
谷岡 康 $^{1} \cdot$ 福岡 捷二 ${ }^{2}$ \\ 1 正会員 工博 パシフィックコンサルタンツ（株） 水工技術本部 河川部 （广163-0730 新宿区西新宿 2-7-1） \\ E·mail: yasushi.tanioka@tk.pacific.co.jp \\ 2フェロー会員 Ph.D 工博 広島大学大学院教授 工学研究科社会環境システム専攻 \\ （テ739-8527 東広島市鏡山 1-4-1） \\ E-mail: sfuku@hiroshima-u.ac.jp
}

\begin{abstract}
都市域の河川・下水道の流出・氾濫は相互に関連し合う治水システムであり，その浸水被害を全体として最小限にす るためには，超過洪水に対する危機管理施策を事前に講じておくことも必要ではあるが，毎年の様に発生する都市型水 害に対して，河川，下水道の整合のとれた治水計画における連携が目前の最重要課題であり早急に進めなければならな いことと考える. 本文は，下水道が整備され河川一自然排水される様な台地部の都市域中小河川・下水道流域を対象と して, 下水道と中小河川で一般的に用いられる合理式に基づく各々の計画で進めている治水計画の現状に対して, 降雨・ 流出特性の実態整理や具体的・実際的なケーススタディを通して問題点を示し，合成合理式等の下水道小流域の流出を 考慮出来る流出解析手法を用いた河川・下水道の連携した治水計画を行う方法を示し，今後の課題を明確にする.
\end{abstract}

Key Words :flood control measures in urban area, coordination of rivers and sewers, torrential rainfalls, composite rational method

\section{1. はじめに}

近年流域の市街化が進み, 流出の速く大きくなってきた 都市域の中小河川・下水道では, 局所的な集中豪雨により, いわゆる都市型洪水の被害が毎年のように発生している. 本論文は, 下水道施設が整備され速く大きな流出が河川 一自然排水される台地部の既成市街地を対象としている. 台地部の都市型水害の特徵として, 中小河川の流出, 沫濫 形態が，下水道の流出・内水汇濫によって大きく左右され ていることが挙げられ，河川，下水道施設の流出量の見積 もり，整備レベルのバランスをいかにとるか，いかに連携 を図るかが, 全体としての被害を低减するための重要な課 題と言える. また都市域では下水道の流出量が，きわめて 速く大きくなってきており, 流域内の下水道流出の重なり 方で河川流量が大きく異なるので, 治水計画で一般に用い られてきた合理式が実態と合わない不具合が生じてきて いる. その意味で下水道・河川での治水対策における整合 と連携が，特に重要となってきていると考える.

現在の河川と下水道の管理分担区分についての通達 ${ }^{1)}$ (昭和 47 年, 建設省)によると, 河川・下水道の流域面積の 境は原則として $2 \mathrm{~km}^{2}$ とされている. これが下水道の排水
区単位の目安となろう.これに対し中小河川の流域スケー ルは概ね $200 \mathrm{~km}^{2}$ 末満 ${ }^{2)}$ が目安となっており, 各々で合理 式により治水計画がなされているのが現状である.

下水道においての雨水排除計画は，「下水道施設計画・ 設計指針と解説」3) に従い行われてきた. ここでは合理式 を原則としており，その施設整備の確率年は $5 \sim 10$ 年とさ れている. 一般に下水道の施設は, 市街地の雨水をすみや かに域外一排除する施設として設計され，治水安全度が河 川より小さいことには留意されるが，その排水先である河 川での現象は考慮されていない.

下水道の最近の流出解析には, 海外で開発された汎用モ デル4) が用いられるようになり，下水道幹線のみならず枝 線までの細かな水路網を解析的に計算出来る様になって きている. また，近年では例えば肱岡ら ${ }^{5)}$ による細密な下 水道施設データベースを用いて, 容易に細かに解析出来, 下水道枝線網についての弱点やマンホールからの溢水箇 所についても解析出来るまでにいたっている．しかし，現 状においては河川との接続箇所における河川水位と下水 道排水量の関係や, 内水による地表氾濫流と河川溢水氾濫 流との相互の影響, 施設能力を超える規模の洪水に対して 河川も含めた総合的な被害の評価等についてを雨水排水 計画にまで反映されるところまでには至っていない． 


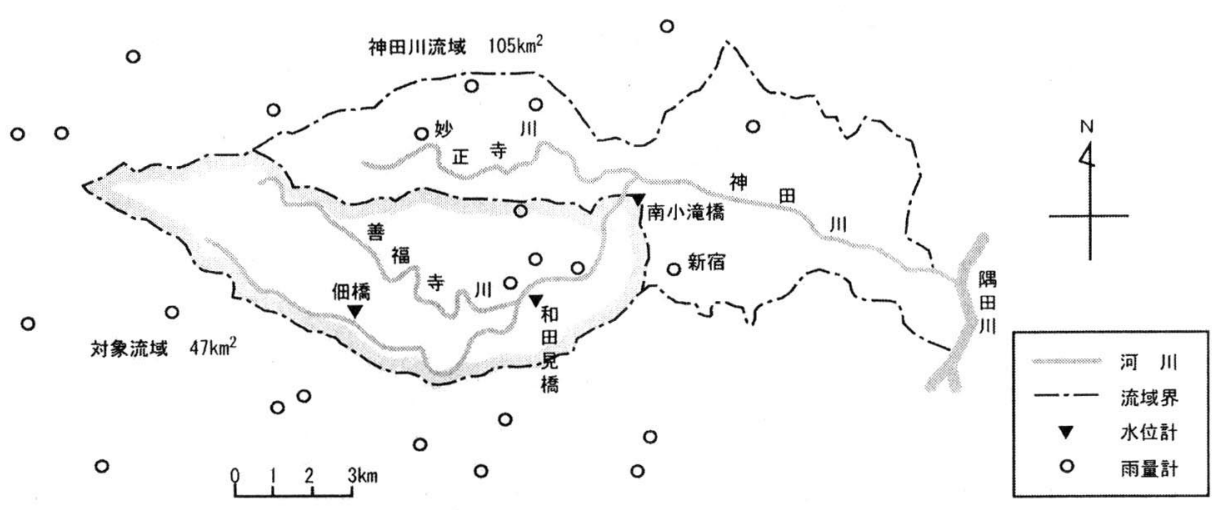

(a) 神田川流域図 ${ }^{20)}$

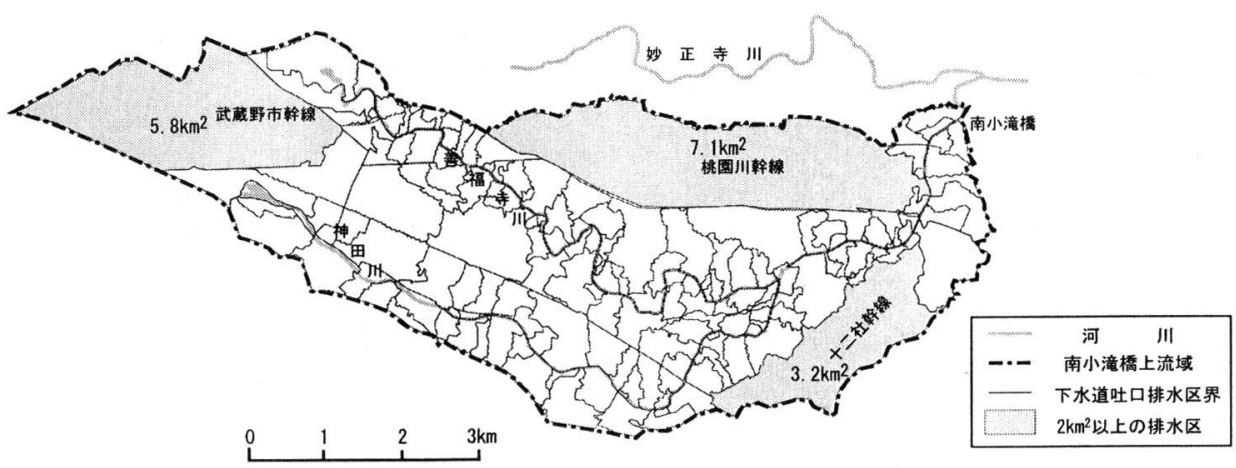

(b) 下水道雨水排水区 (河川吐口単位) の概況

図一1 東京都神田川及び下水道流域図

中小河川の治水計画は，「改訂 建設省河川砂防技術基 準 (案) 計画編」 ${ }^{6)}$ に基づいて行われてきている.ここで は, “100 km $2 \sim 200 \mathrm{~km}^{2}$ の中小河川では, 合理式を用いて 計画が行われていることが多い”とされている. 中小河川 の計画においては, 今まで雨量, 水位の記録が細かに得ら れず，また下水道流域の流出形態を細力に把握出来なかっ たことも一因として，計画上の流量は便宜的に合理式を用 い見積もられてきた。

都市中小河川の流出に関する研究は，その市街化による 影響を予測することを目的に古くに行われてきた. しかし， 多くの研究は，今日までの市街化が進んだ状況でなかった こと, 雨量や水位の記録が時空間的に密に得られなかった ことにより，市街化による流出特性の変化は想定の域を出 ていない，一般に，都市化された流域は，様々な下水道施 設の整備, 不浸透域・浸透域の混在等から複雑な排水シス テムを形成しており，この流出を再現するモデルとして， 山口ら ${ }^{7)}$-9) の修正 RRL 法，橋本・長谷川 ${ }^{10)}$ の隻線形貯
留型モデル, 和泉・吉川 ${ }^{11)}$ の修正 RRL 法と貯留関数法を 組合せる方法等, 様々な非線形的手法が検討され，これら を用いて市街化の影響量が検討されているが, 決定的方法 は得られていない，また，現在の極度に市街化の進んだ流 域に対しての検証を行った例は少ない．

著者らは，東京都で得られた密な雨量・水位データをも とにして, 都市中小河川流域スケールでの降雨の時空間的 な分布・変動の特性 ${ }^{12)}$ １5) 及び狭小域の降雨とその流出の 線形的な関係 16) 18) をもとにして, 降雨の時空間的な分 布や変動を細かに流出に反映できるように小流域毎の合 理式による流出流量を重ね合わせる線形モデルを構築し， その再現性を示し, 都市中小河川の流出の実態と特性を, 特に降雨の地域分布との関係で明らかにしてきた ${ }^{199,20)}$.

また, 都市中小河川流域規模での時々刻々の降雨の空間 分布の不均一性が流出に与える影響を検討し, 合理式の適 用範囲については，特に雷雨性の降雨に対して，せいぜい 流域面積 $5 \mathrm{~km}^{2}$ までと考察している ${ }^{20)}$. 

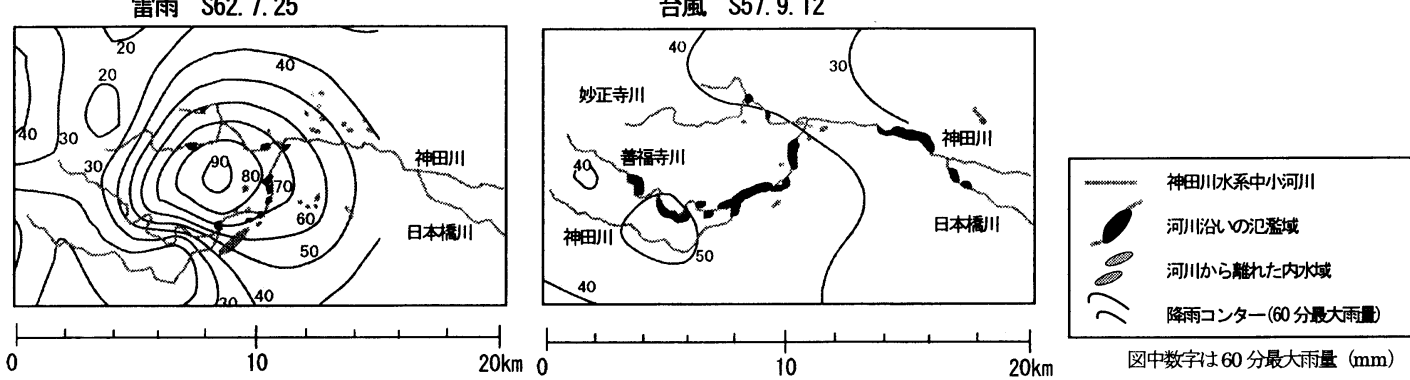

図一2 降雨要因と浸水実績 ${ }^{19}$

本論文は，都市化の進んだ台地部既成市街地での中小河 川・下水道を対象に，いままでの合理式で考えてきた計画 流量と，合成合理式を用いた下水道の小流域の速く尖鋭な 流出が重なりあう場合の流出量の違いをケーススタディ により示し，河川・下水道の連携した治水計画を行うため の流出解析手法についての要件を示した. また集中豪雨な ど実績の降雨の時空間分布を与えた場合の検討事例を通 して，今後の中小河川・下水道の連携した治水計画を行う 上での留意点, 課題について考察した.

\section{2. 台地部中小河川 - 下水道の降雨 - 流出 - 汇監特性}

\section{（1）台地部の中小河川 - 下水道の流域スケール}

本論文では図一1 (a) に示す東京の代表的な都市中小河 川である神田川流域のように，台地部にある都市域の中小 河川と下水道を対象としている. 台地部の都市流出の特性 として，下水道の流出量が，低地部ではポンプ場などによ り強制的に排水されるのに比べ，下水道施設能力に見合う 流量が河川に自然排水されることにある.

図一1 (b)に神田川の中・上流部 (約 $50 \mathrm{~km}^{2}$ ) の河川への 下水道吐口による排水区界を示寸，下水道流域は，河川流 域のスケールより小さく, 3 つの幹線以外は, $2 \mathrm{~km}^{2}$ 以下 となっている. これら大小含めた下水道流域からの流出の タイミング, 重なり方が河川の流量ハイドログラフを規定 することとなる.

\section{（2）降雨要因と浸水被害}

近年の都市部の洪水被害は, 主に台風性豪雨によるもの と雷雨性の集中豪雨によるものとに分けられる. 図一2に は, 神田川での雷雨, 台風による実績の浸水範囲を示す. 雷雨性豪雨では短時間雨量が卓越し下水道施設が排水し きれずに, 河川から離れた部分での内水被害が顕著である. これに対し, 台風では短時間の降雨強度が比較的小さいた め, 下水道から順調に河川 排出され, 河川沿いでの溢水 氾濫が顕著となっている. この様に降雨要因によって異な

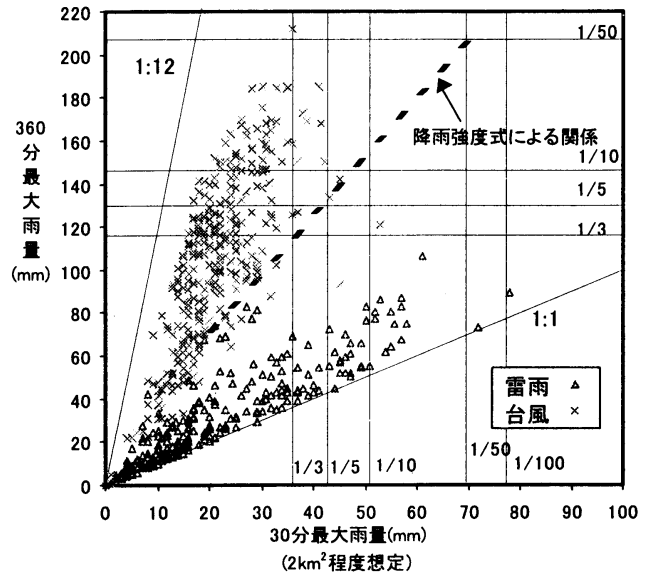

図-3 降雨要因と短時間雨量

る流出・氾濫形態を示すのが，下水道施設が整備された既 成市街地での都市型水害の特徴といえる.

図-3 に東京都神田川流域内で浸水被害の発生した 10 の降雨（雷雨 5 降雨，台風 5 降雨）時の東京都内に複数設 置されている降雨観測所での 10 分雨量記録から，横軸に 下水道の排水区 $2 \mathrm{~km}^{2}$ 相当での流達時間とした 30 分での 最大雨量, 縦軸に河川での $200 \mathrm{~km}^{2}$ の流域面積を想定した およその到達時間 360 分 (6 時間) 程度とした場合の最大 雨量の関係を示した. 台風性と雷雨性の降雨要因による到 達時間内雨量の関係は，明確に分かれることがわかる.

この様に実際に浸水被害をもたらす降雨の時間分布は, 降雨要因により特徴的であり，この降雨外力の特性により 図一2 に示す様な浸水被害の特性も左右されることとなる. 図-3 中に点線で示しているのは，確率規模毎の降雨強度 曲線から求めた 30 分, 360 分雨量の関係であるが, 台風 性降雨と雷雨性降雨の分布の間で台風よりに位置してい る. 降雨の実態としてはこの 30 分, 360 分雨量が同時に 生起することはまれであろうことが推定される.

この様に降雨要因, 降雨の時空間分布特性により, 流出 や内水·外水の氾濫特性も, 様々な様相を呈しているので, 


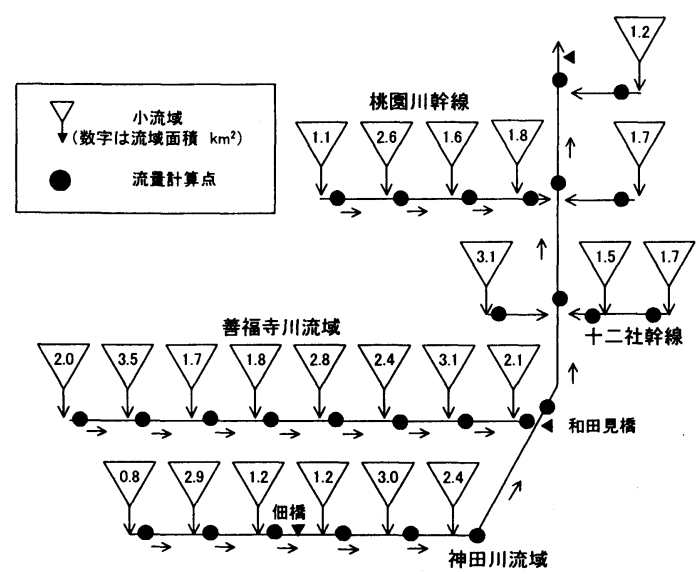

図-4 洪水解析モデル（合成合理式） ${ }^{20)}$
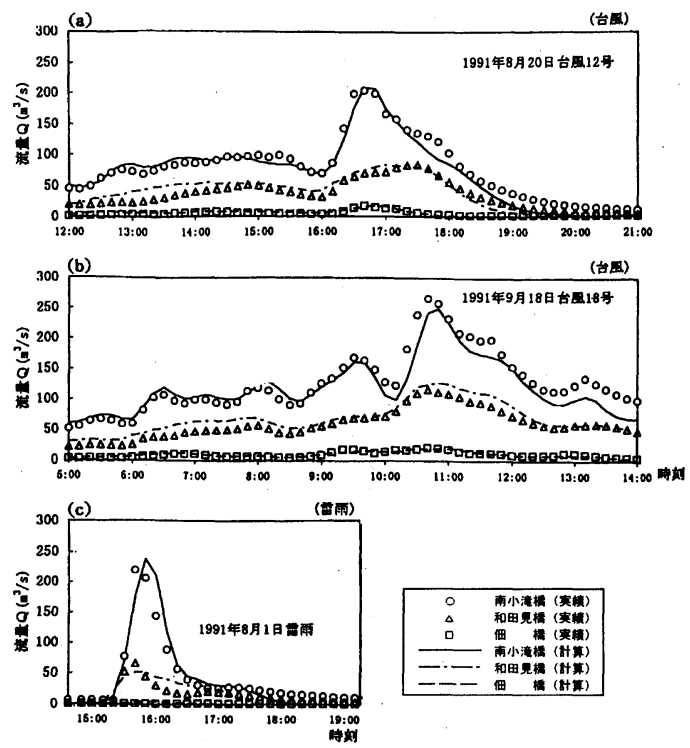

図-5 実績洪水の再現結果 ${ }^{20)}$

治水対策においてもこれら実際の降雨の時空間分布に対 応する計画が重要となると考えられる.

\section{（3）都市中小河川の流出の再現性}

著者ら ${ }^{20)}$ は, 図一1 (a) で示寸神田川南小滝橋上流（約 $\left.50 \mathrm{~km}^{2}\right)$ を，図一4に示すようなおよそ $1 \sim 3 \mathrm{~km}^{2}$ 程度の小 排水区で分割した合成合理式 ${ }^{2)}$ での実績洪水による再現 を試みている. 結果は図一5に示すように波形，ピークと も極めて良好に再現出来ることとなり，流域内の短時間 (10 分) 降雨の地域分布の細かな反映と, 小流域の流出量 の線型的な重ね合わせにより対象域の流出現象を良好に 再現出来ることを示している. ただし，この検討では下水 道・河川の汇濫のない規模での洪水を対象としているため, 内・外水の汇濫がある場合までの流出量は再現出来ない．

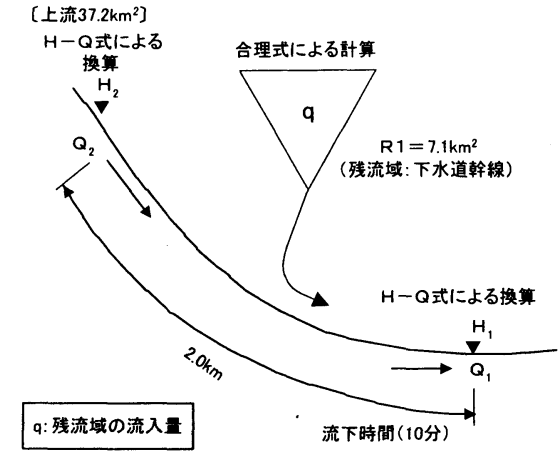

図一6 流出流量推定模式戝 ${ }^{20)}$

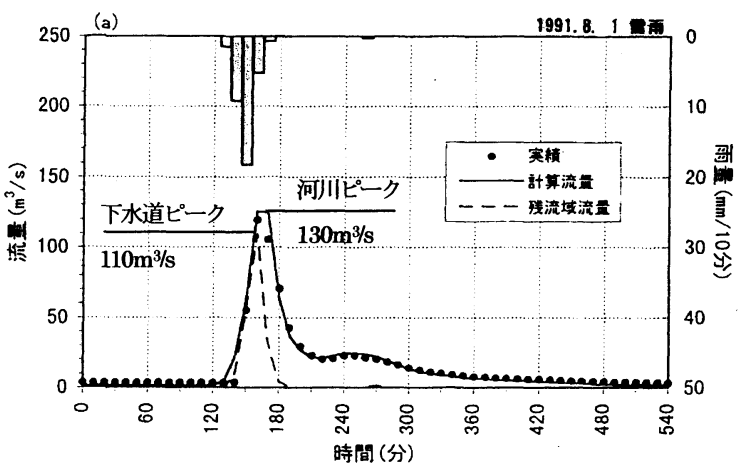

図一7 河川流量と下水道幹線流量 ${ }^{20)}$

\section{（4）下水道の流出の河川への影響}

神田川の水位計が比較的近傍にあり，その間に下水道幹 線が流入する区間を抽出し, 下水道の流出形態を調べ20). 検 証は，図一6 に示す模式図の様に，上流実績水位加 $\mathrm{H}^{-}$ Q式で換算した流量に残流域流出量を加えたものと，下水 道幹線合流後の実績水位から $\mathrm{H}-\mathrm{Q}$ 式で換算した流量とを 比較し再現性を調べている. 残流域（下水道幹線）の流出 量は，流域規模，下水道の流下時間等を考慮し，到達時間 を 30 分と想定し, 10 分毎の降雨波形から 30 分間の移動 平均降雨強度を求め, 合理式により時々刻々の流出量を算 定している. 図一7に示寸様に下水道幹線合流後の流量は 良く実績値を再現している. これより下水道幹線の流出の 仕方は，降雨波形に極めて線形的で尖鋭であり，下流流量 のピークに大きく支配的となっていることが分かる.この 雷雨性の降雨においては, 洪水の立ち上がり部に近傍の下 水道流域の流量が重なり, 本川ピーク流量の約 8 割を支配 していることとなる.

このことから, 都市中小河川の流出量は下水道の速い尖 鋭な流出量とその重なり方が大きく影響するので, この点 を正確に把握することが, 治水計画を行う上で重要である ことが分かる. 


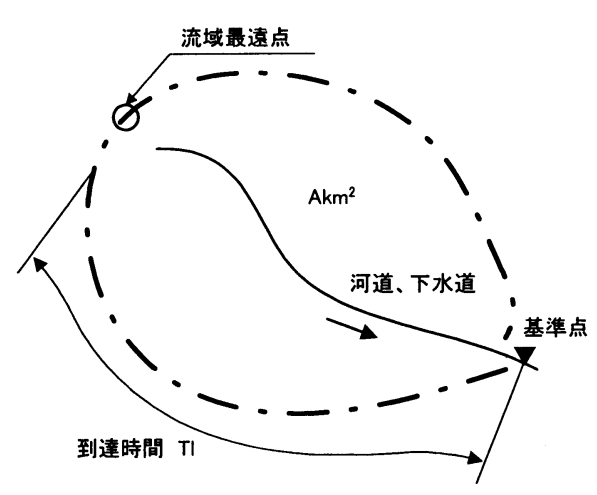

図-8 流域模式図

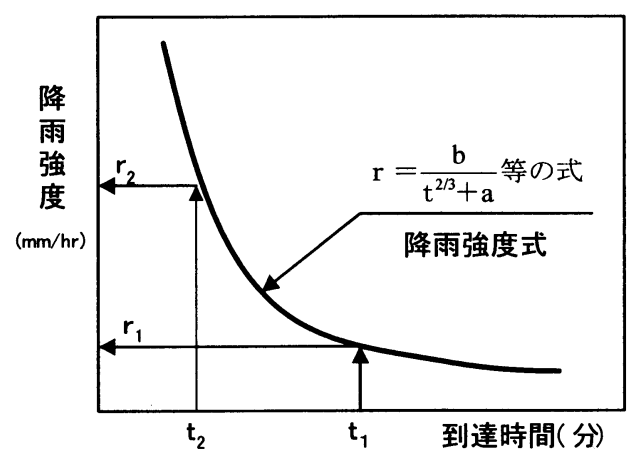

図一9 降雨強度式の概念図

\section{3. 治水計画における流出解析手法について}

\section{（1）合理式による計画の現状と課題}

\section{a）河川・下水道計画での合理式適用の現状}

下水道では一般に管理区分界である $2 \mathrm{~km}^{2}$ 以下の排水区 に対して合理式に基づいて雨水排水計画が行われており， また流域面積が 100 200 $\mathrm{km}^{2}$ 以下の殆どの中小河川でも 同様に合理式が用いられている. 合理式においては, 流域 面積と流域最遠点までの到達時間だけで計画流量が定め られるもので, 下水道からの尖鋭な流出現象やその重なり 方などは見込まれていない

都市中小河川の流出形態は, 小流域の短時間雨量に即応 した直接的な流出 ${ }^{20)}$ に支配され，流域途中の各小流域か らの尖鋭な流出とその重なり方が直接的にピーク流量や ハイドログラフを規定する流出形態で, 流域が大きくなる ほど合理式の仮定 ${ }^{21)}$ である “流域最遠点からの到達時間 内降雨強度が時空間的に一定”が成立しないと考えられる。
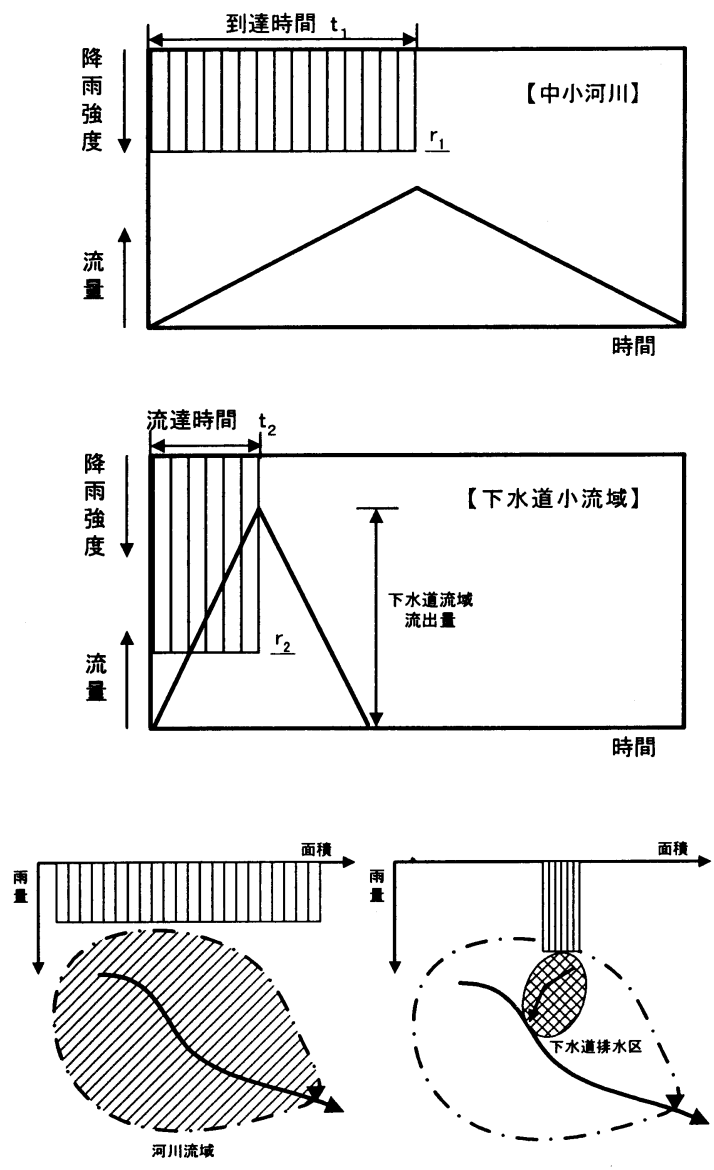

図-10 合理式の概念図

\section{b) 合理式の前提・仮定と課題}

合理式では, 図一8に示すように流出量を求める基準点 からの上流域を一括した単流域とみなし，流域の最遠点か らの到達時間に見合う降雨強度を用いて次式により算定 する.

$$
\mathrm{Q}=\frac{1}{3.6} \cdot \mathrm{f} \cdot \mathrm{r} \cdot \mathrm{A}
$$

ここに, $\mathrm{Q}$ : 流出量 $\left(\mathrm{m}^{3} / \mathrm{s}\right), \mathrm{f}$ : 流出係数, $\mathrm{r}$ : 到達 時間内降雨強度 $(\mathrm{mm} / \mathrm{hr}), \mathrm{A}$ : 流域面積 $\left(\mathrm{km}^{2}\right)$ である.

ここでの到達時間内降雨強度は，実績の様々な継続時間 の年最大雨量を用いて統計的に処理し，図一9に示寸様な 降雨強度式にあてはめたものを用いている. 図一10に合理 式の概念を示寸. 中小河川においては, 長い到達時間 $\mathrm{t}_{1}$ に よる降雨強度が継続すると仮定している. また，下水道の 小流域では $\mathrm{t}_{2}$ の流達時間に見合う流出量のピークが算定 される.ここでは基準点に対する上流域の降雨の一様性と 


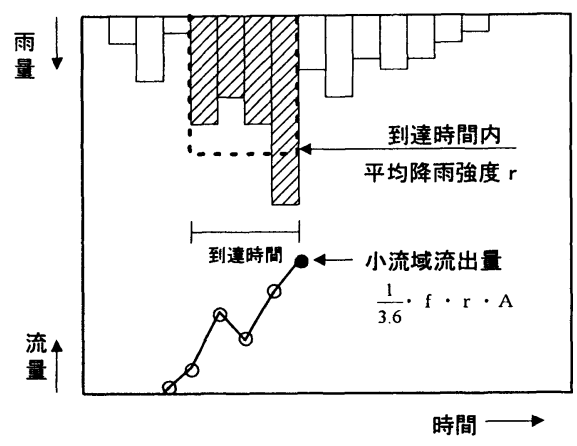

図-11 合成合理式の流出計算の概念

到達時間内の降雨強度の一様性が重要な前提となってい る. つまり下流河道の基準点では, 継続時間の長く弱い降 雨が流域全体に降った場合を流出量としている.

流域面積，到達時間が長くなる程，都市中小河川流域の 小さな時空間スケールの降雨特性 22) からもわかるように 降雨の時空間的な一様性の前提が実態と乘離してくる. 一 方で，河川に流入する下水道の小流域では，図一10中・下 段に示すように短い時間の強い降雨による尖鋭な流出を 対象に計画される.ここで, 下水道小流域と河川流域では, 計画上考えている対象降雨 (強度) が異なっていることに なる.

合理式の仮定は，流域一律で，流域最遠点からの到達時 間の間は一定の降雨強度が続くという前提であるが, 到達 時間や流域面積が長く, 広くなる程その現実性が薄れる. 合理式の適用範用について検討された例は少なく, 吉野 ${ }^{21}$ は合理式の適用範用は $10 \mathrm{~km}^{2}$ 以下が望ましいとしている が，明確な根拠についてまでは言及されていない，また著 者ら ${ }^{20)}$ は, 実績降雨の要因別の時空間的な一㥞性から, 雷雨性降雨でおよそ $5 \mathrm{~km}^{2}$, 台風性降雨で $30 \mathrm{~km}^{2}$ が限度で あろうとしている。「中小河川計画の手引き」2)では，合 理式の適用は $50 \mathrm{~km}^{2}$ 未満を目安としており，流域を細か に分割する合成合理式 ${ }^{2)}$ の概念をとりいれている.

Viessman\&Lewis ${ }^{23)}$ によれば，合理式の適用範囲を 600acre（約 $2.4 \mathrm{~km}^{2}$ ） 以下としている例もあり，海外での 合理式の適用範用は極めて小さい. いずれにしても 100 〜 $200 \mathrm{~km}^{2}$ の中小河川流域を一括流域で扱う合理式を実態と しての流出計算に適用することは合理的でないと考えら れる.

\section{（2）下水道流出の重なり方の河川流量への影響}

\section{a) 検討方法}

本検討では，下水道の流入の仕方と重なり方による河川 流量の差異や，降雨の時間分布，地域分布が河川流出量に
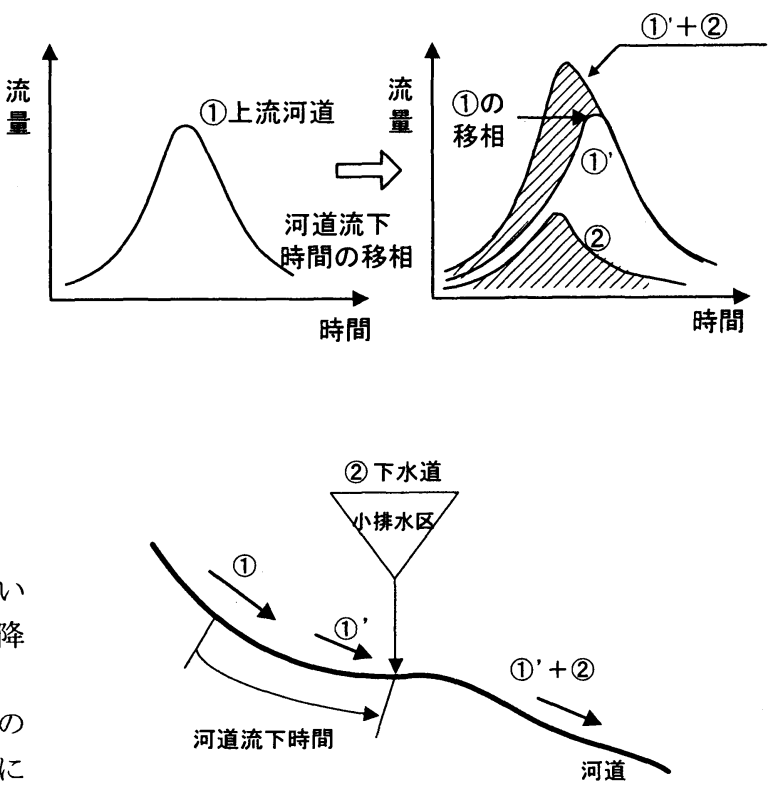

図一12 合成合理式の流出量の重ね合わせの概念

与える影響を調べるために, 分割した各小流域の流出量を

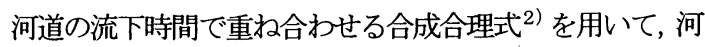
川の流出量が基準点上流を単流域と把える合理式とどの 程度異なるかを試算する。

合成合理式は，まず対象流域を小流域に分割し，各小流 域の降雨波形から図一11に示すように, 時々刻々の到達時 間内の移動平均降雨強度を算出し, 合理式を用いて小流域 の流出量を算出し，重ね合わせる方法である. 図一12 に示 す様に(1)上流河道の流量を河道流下時間分移相させた波 形(1)に(2)の下水道小流域の流出量を線形的に加えていく 方法である. この力法は, 降雨の時空間分布，下水道流出 量の重なり方を考慮出来るものであり，前述のように汇濫 のない範囲では台地部での都市中小河川での流出現象を 再現できることが検証されている ${ }^{20)}$.

本検討では，まずこの合成合理式と，合理式による流出 量の差異をもとに，河川・下水道での治水計画における問 題点・課題を明らかにする.

ここで検討に用いる降雨強度式は, 東京都の中小河川で 当面の計画として用いられている ${ }^{24)} 3$ 年確率 (1 時間当 たり $50 \mathrm{~mm}$ ）の次式を用いる事とした.

$$
r=\frac{1100}{t^{2 / 3}+6.5}
$$

ここに $\mathrm{r}$ : 到達時間内降雨強度 $(\mathrm{mm} / \mathrm{hr}), \mathrm{t}$ ：到達時 間（分）（下水道では流達時間）である. 
流入 30 分

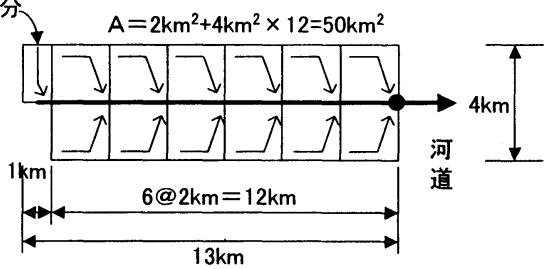

図-13 合成合理式モデル概念図

(1)最上流 流入ブロック $\left(2 \mathrm{~km}^{2}: 30\right.$ 分)

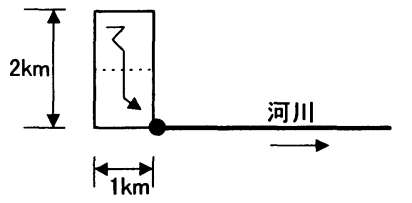

(2)中流流入ブロック $\left(4 \mathrm{~km}^{2}: 35\right.$ 分)

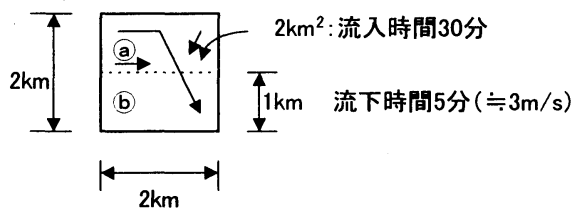

図-14 各小流域の流出条件の設定

対象とする中小河川の流域面積は神田川の中上流の台 地部を想定し $50 \mathrm{~km}^{2}$ とした.

合成合理式の解析モデルは，図一13 に示す様に $50 \mathrm{~km}^{2}$ の河川流域内を $4 \mathrm{~km}^{2}$ (最上流 $2 \mathrm{~km}^{2}$ ) の小流域（下水道 排水区）に設定した. ここで, 流出係数は一般市街地を想 定し $\mathrm{f}=0.8^{6)}$ とし, 到達時間は, 図一 14 に示寸様に, 最 上流の $2 \mathrm{~km}^{2}$ は河川の計画に用いられている “下水道整備 区域の $2 \mathrm{~km}^{2}$ に対して 30 分の流入時間” ${ }^{6)}$ を用い，河道 の流下時間は, 洪水の伝播する速度を約 $3 \mathrm{~m} / \mathrm{s}$ と想定し, $1 \mathrm{~km}$ 相当の水路, 河道に対して 5 分を与えるものとした. 合成合理式においては, $4 \mathrm{~km}^{2}$ 単位の排水区も 2 分割し, 最小流域単位を $2 \mathrm{~km}^{2}$ として 25 流域のモデルを作成した. ここで,このモデル流域での合理式に用いる最遠点からの 到達時間は 90 分となり, そのときの到達時間内降雨強度 は式(2)を用いれば, $\mathrm{r}=41.4 \mathrm{~mm} / \mathrm{hr}$ で, 合理式によるこの $50 \mathrm{~km}^{2}$ 流域の流出量は式(1)を用いて

$$
\mathrm{Q}=\frac{1}{3.6} \mathrm{f} \cdot \mathrm{r} \cdot \mathrm{A}=\frac{1}{3.6} \cdot 0.8 \cdot 41.4 \cdot 50=460 \mathrm{~m}^{3} / \mathrm{s}
$$

となる.これが通常の合理式による計画では河川の下流端 の計画流量とされる.

\section{b）流域形状による流量の差異}

図-15 に同じ $50 \mathrm{~km}^{2}$ の流域面積で，最遠点からの到達 時間 90 分を同じくした, 4 つの流域形状モデルを示す.
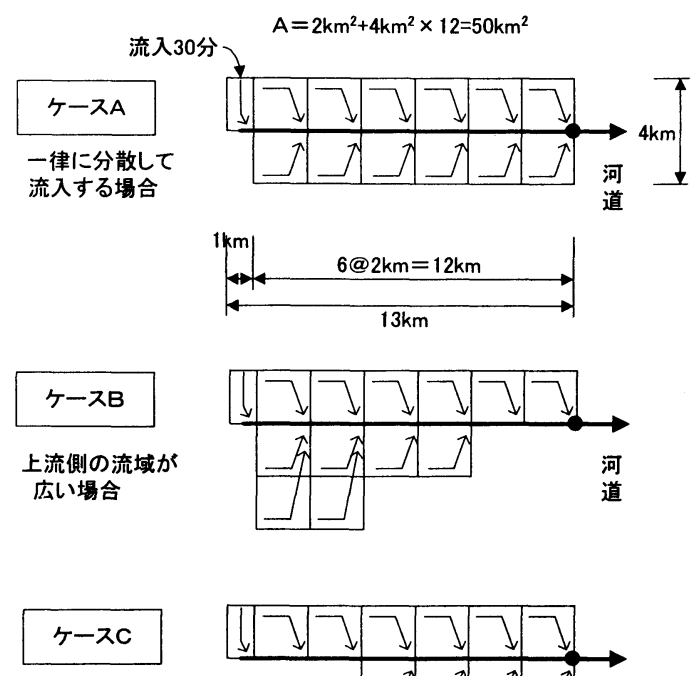

下流側の流域が 広い場合
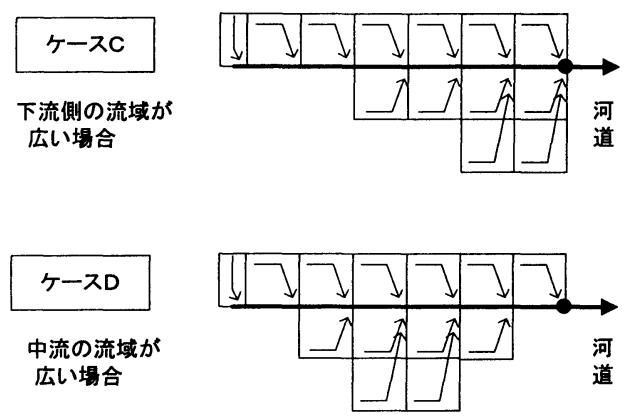

図-15 $50 \mathrm{~km}^{2}$ の流域形状試算ケース

合理式においては流域の形状, 例えば下流側が広い等の条 件は考慮されないし, 最遠点でない途中流域の下水道小流 域の流出の状況，重なり方は考慮されない.つまりどの流 域形状でも式(3)での $460 \mathrm{~m}^{3} / \mathrm{s}$ が計画の流出量となる.

合成合理式に用いた中央集中型降雨波形は, 図一16 の雨 量グラフに示すようにピークを挟んだ到達時間内雨量強 度を確率規模毎の降雨強度曲線による雨量と便宜上合わ せた計画降雨波形であり, 中小河川や下水道において, 貯 留施設を計画する場合にハイドログラフが必要とされる 場合に用いられることが多い

図-16 に図-15 で示すケースAからDまでの流域形状 によって, 合成合理式を用いた場合にどの程度流量が異な るかを試算した結果を示す。この結果では, 中流域, 下流 域に流域が広い場合に最も大きい流出量となる。これは， 各小流域の尖鋭な流出と上流からの流量が, タイミングよ く重なることにより大きな流量を示していると考えられ る. 流出量は, 表一1に示すように通常の合理式で与えられ る計画流量に比べて約 2 割から 3 割増となることがわかる. これに比べて, 流域形状による影響はおよそ 1 割程度 $(129 \%-118 \%)$ となり, 合理式を合成合理式とし小流域 流出量の重なり方を考慮したことによる影響の方が大きい 


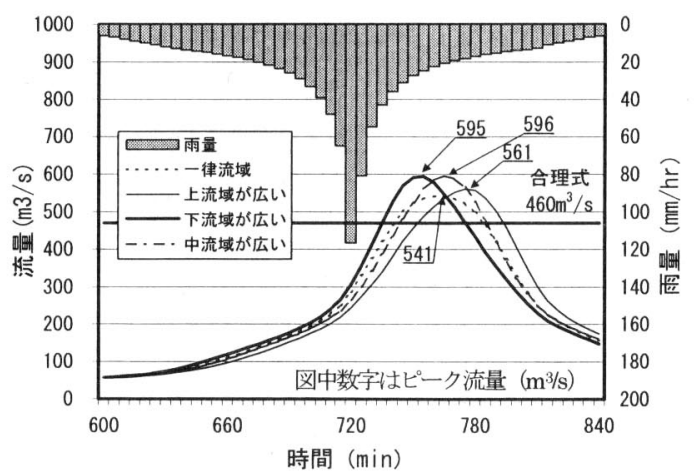

図一16 流域形状による流出流量の相違

表-1 モデル流域 $\left(50 \mathrm{~km}^{2}\right)$ の試算結果一覧表

\begin{tabular}{|l|c|c|}
\hline 流域形状 & $\begin{array}{c}\text { ピーク流量 } \\
\left(\mathrm{m}^{3} / \mathrm{s}\right)\end{array}$ & $\begin{array}{c}\text { 中小河川合理式流量 } \\
460 \mathrm{~m}^{3 / 3} \text { に対する比 }\end{array}$ \\
\hline A. 均一流入 & $\begin{array}{c}541 \mathrm{~m}^{3} / \mathrm{s} \\
\left(561 \mathrm{~m}^{3} / \mathrm{s}\right)\end{array}$ & $\begin{array}{c}118 \% \\
(119 \%)\end{array}$ \\
\hline B. 上流広 & $561 \mathrm{~m}^{3} / \mathrm{s}$ & $122 \%$ \\
& $\left(570 \mathrm{~m}^{3} / \mathrm{s}\right)$ & $(124 \%)$ \\
\hline C. 下流広 & $595 \mathrm{~m}^{3} / \mathrm{s}$ & $129 \%$ \\
& $\left(614 \mathrm{~m}^{3} / \mathrm{s}\right)$ & $(133 \%)$ \\
\hline D. 中流広い & $596 \mathrm{~m}^{3} / \mathrm{s}$ & $129 \%$ \\
& $\left(613 \mathrm{~m}^{3} / \mathrm{s}\right)$ & $(133 \%)$ \\
\hline
\end{tabular}

（）内は，最小排水区 $2 \mathrm{~km}^{2}$ の流入時間を 30 分から 20 分一短く なったと想定した場合

\section{といえる.}

また表-1 の括弧で示しているが，下水道の小流域 $2 \mathrm{~km}^{2}$ の流入時間が，通常河川で想定する 30 分 ${ }^{6)}$ から 20 分と短かった場合については，さらに 2〜4\%ではあるが 大きな流量となり, 留意が必要であることがわかる.

\section{c）降雨の地域分布による流量の差異}

降雨の空間的な偏差, 流域に対する集中域が，流出量に 与える影響を検討した．図一17 に示㥞に対象流域内の 降雨分布を上・中・下流の 3 ブロックに分けて, 集中域に は時間当たり $75 \mathrm{~mm} / \mathrm{hr}$ の降雨を与え，その隣のブロック では $50 \mathrm{~mm} / \mathrm{hr}, 25 \mathrm{~mm} / \mathrm{hr}$ とし, 比較のために流域平均と しては $50 \mathrm{~mm} / \mathrm{hr}$ の降雨強度となるように調整した。この 降雨分布は（後に示寸図一26の No.9 集中豪雨のように) ピーク雨量発生地域に対して $5 \mathrm{~km}$ 程度離れると，その半 分程度の雨量分布となる実績もあり，実際に起きうる集中 豪雨の分布として想定される.

図一18にその試算結果を示寸. 流域平均雨量としては合 理式と同等の外力であり, 合理式の場合に比べ 2 割 3 割 の流出増となっている．また，流域一律のケースである $541 \mathrm{~m}^{3} / \mathrm{s}$ に比べ，どの集中域のケースも，大きく計算され

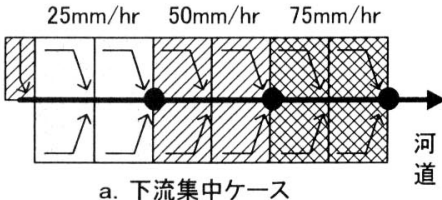

a. 下流集中ケース

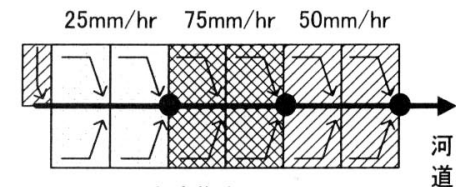

b. 中流集中ケース

道

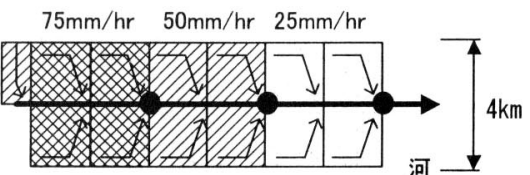

c. 上流集中ケース

道

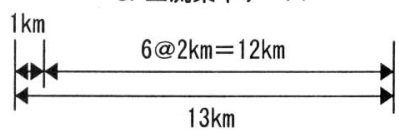

図ー17 降雨の集中位置のケース

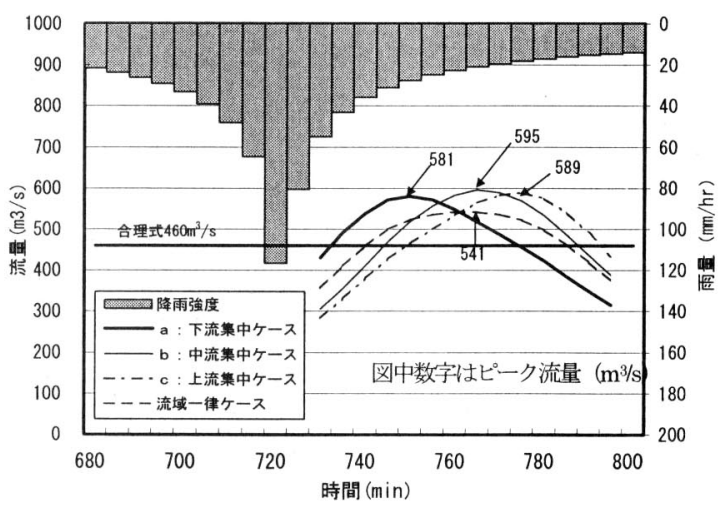

図-18 降雨集中域による流出流量の相違

ることとなる.これは，ひとつの集中域でほぼ同時に重な る下水道流量が大きい程，それが河川のピーク流量に效い てくるためと考えられる. 降雨の集中域によっては, その 流出流量, 流出形態 (ピーク時間等) は様々となる. $50 \mathrm{~km}^{2}$ 程度の流域でも，流域に平均的に降雨がある場合に比べて 下流に降雨が集中寸るケースで, 合理式に比べて 3 割もの 流量增となり, ピーク流量が約 20 分速くなる.

\section{d）河川 - 下水道の超過外力に対する流量}

下水道の整備計画のレベルは，原則として $1 / 5 \sim 1 / 10$ 確 率 ${ }^{3)}$ であり一般的に河川に比べて低い.このことから下水 道が完備された都市流域では, 往々にして集中豪雨等によ り下水道施設能力を超えて内水氾濫を起こし，その分河川 


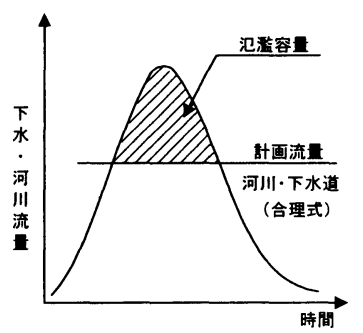

図-19 氾濫量の推定
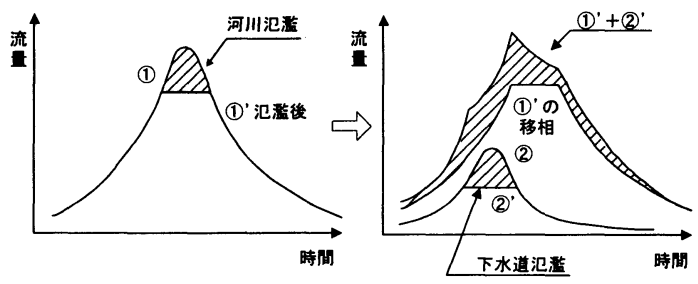

図-20 河川下水の汇濫後の重ね合わせ

一排水されず河川が下水道に比して余裕がある場合があ る. 一方で, 下水道施設は合理式により短時間の強い降雨 強度で設計されるので, 台風の様に比較的弱い降雨強度が 長時間続く場合には，下水道は余裕を持って排水される代 わりに，全体として河川に集中して汇濫する場合もある.

これらの氾濫について，その影響がどの程度河川流量に 効くかを調べるために簡易的に内・外水の氾濫を見込める モデルを検討した.

図一19に河川, 下水道の能力を超える洪水での氾濫の考 え方を示す.ここでは, 河川, 下水道の能力を合理式によ る計画流量とし，それを超える流量は内水，外水の汇濫量 とした. 河川・下水道の流量は, 図一20に示すように河川・ 下水道の能力以上を汇濫量として除外した流量ハイドロ グラフを流下時間で移相させて重ね合わせることとした。

図一21に中央集中型降雨に対するこの汇濫を考慮した 場合の計算結果を示す. このケースでは河道の氾濫容量は 各所で 3.4 万 $\mathrm{m}^{3}$ となり下水道の 0.2 万 $\mathrm{m}^{3}$ に比べ大きい. この様な下水道での沉濫と河道での汇濫は複合的に発生 し, 各々の施設能力の組合せにより内外水の汇濫容量が変 わってくる. 図一22に中上流での河道・下水道の汇濫を考 慮した場合としない場合の河川下流端での流量ハイドロ グラフを示す. ピーク流量は汇濫を考慮しない $541 \mathrm{~m}^{3} / \mathrm{s}$ に 比べ $504 \mathrm{~m}^{3} / \mathrm{s}$ と約 1 割減となった. また, 氾濫のある場合 とない場合のボリュームの差は 16 万 $\mathrm{m}^{3}$ となった. この様 なピーク流量やピーク付近の流量ハイドログラフの差異 は，例えばこの河川下流端に調節池等の計画を行う場合に は大きな差となる. この点で, 河川流量は上流での氾濫, 下水道の排水量・流出形態及び内水汇濫形態も把握した上 での見積もりが重要になる.

本解析では，上流での内水等による汇濫水の戻りは考慮

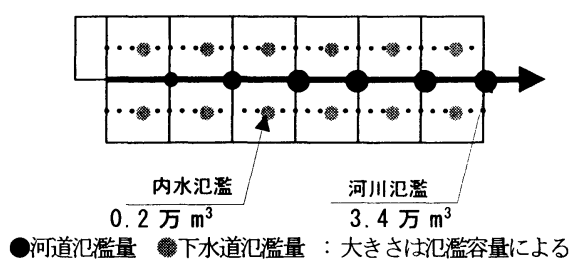

図-21 中央集中型降雨での計算結果

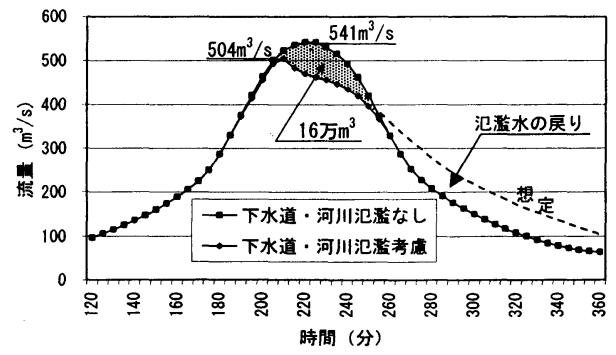

図一22 河川・下水道の氾濫の有無による河川流出量の差

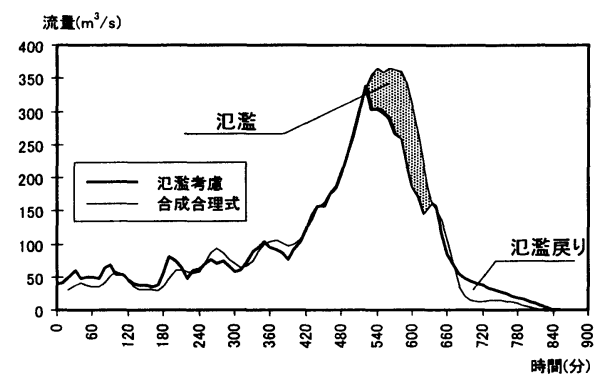

図一23 合成合理式と沫濫を考慮した解析結果の比較

していない，実際には，洪水低减期に河川水位が低下し， 内水汇濫水が排水され河道に戻ることにより, 図一22 の点 線に示すようなハイドログラフとなることが推定される. これらの汇濫水の戻りが, 流量のピークや洪水調節池等の 施設容量に影響する場合には考慮にいれたモデルとする ことが必要である.

図一23には, 汇濫を考慮しない合成合理式と, 対象流域

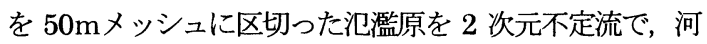
道，下水道幹線を一次元不定流下解析し，内水，外水汇濫 とその戻りも含めた詳細モデルとの解析結果 ${ }^{25)}$ を比較し た. 合成合理式では，氾濫を生じないピークにいたるまで の流出波形では極めて良好に流出波形を再現しているこ とがわかる. また，ピークでの汇濫によるハイドログラフ の欠け方が図一22 で示寸形状ととても似ており, 内水汇濫 等による特性がよく再現できているものと思われる. この ケースでは, 氾濫水の戻りと考えられる差分は低減部の裾 野の方であり，ピーク付近には影響していない。 
図一24４流域モデルの組合せ

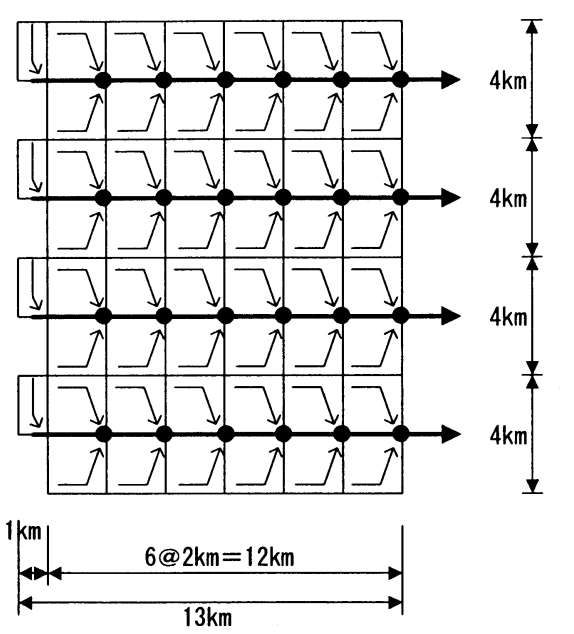

\section{4. 河川・下水道の連携した治水対策}

地域分布をもつ実績の降雨に対する河川・下水道の治水 対策についていくつかの検討例を示す. 図一24 に示すよ うな先の検討の $50 \mathrm{~km}^{2}$ の河川モデルを 4 流域並べたモデ ルを考える．東京都区部山の手の中小河川流域を図一25 に同じスケールで並べているがその流域規模から, 神田川 の中上流部, 白子川, 石神井川及び目黒川程度の 4 河川が 並列している中小河川の組合せを単純化したものをイメ 一ジしている. 対象降雨は, 先述の中央集中型降雨及ひ降 雨外力の時間・空間分布の影響を考慮するために, 台風及 び集中豪雨の実績降雨とした. 計算は, 下水道では河川へ の吐口, 河道では下水道が合流する $2 \mathrm{~km}$ ピッチの基淮点 についてのハイドログラフを先述の合成合理式のモデル を用いて求め, 各計算点においての合理式計画流量を排水 能力としてこれを超える量を汇濫量として計上し, その下 流へは流下しないとしてハイドログラフを重ね合わせる こととした.

\section{（1）河川, 下水道の改修の効果, 影響}

河川・下水道の能力の設定として, 合理式による計画流 量で整備したケース, 及び合理式に比べて実態の流量が 1.2 倍程度になる前述の結果を踏まえて, 下水道, 河川を 合理式での計画流量の 1.2 倍の能力で改修した場合につ いて検討する. 合理式による計画流量は, 河川では各基準 点の上流一括流域での, また下水道にあたっては, 河川 の吐口地点での上流一括 $\left(4 \mathrm{~km}^{2}\right)$ での合理式による流量 を計画流量 (=流下能力) とし, 汇濫量を算定するものと した. ただし, 各 4 河川の下流端河道のみについては, 合 理式における計画流量の流下能力のままとし, 上流下水道, 河道の改修の影響に対する下流への負担の増分や, 下流河

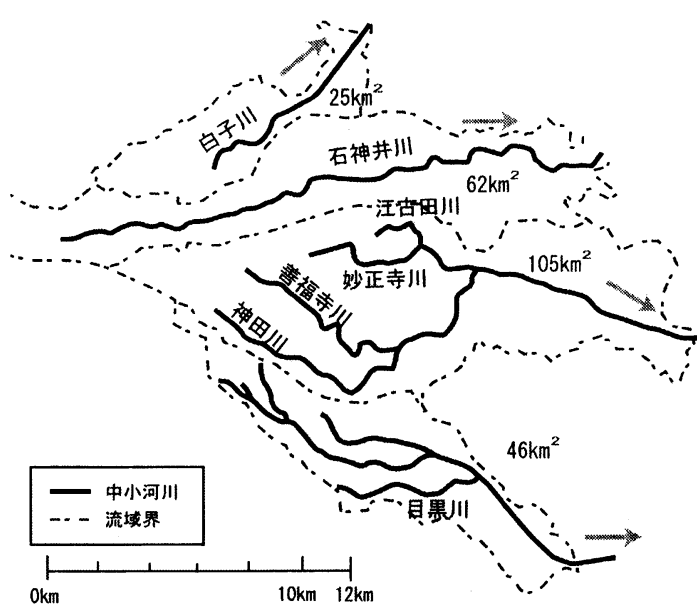

図一25 東京都区部中小河川流域規模 ${ }^{24)}$ との比較

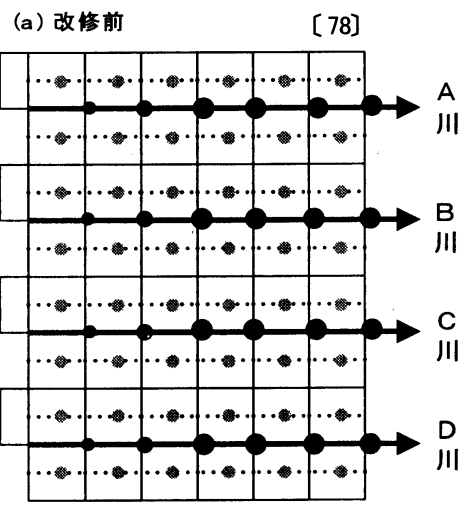

改修後
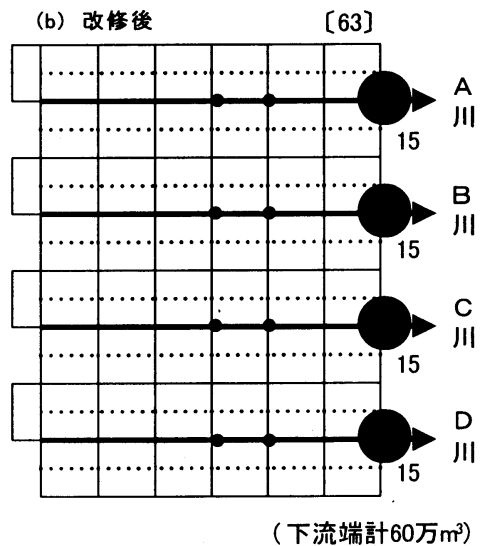

河道氾濫量 下水道氾濫量 ：大きさは氾濫容量による ※図中数字は氾濫容量 $\left(\right.$ 万 $\left.\mathrm{m}^{3}\right)$, うち [ ] 書は, 総氾濫容量 図-26 中央集中型降雨での計算結果 
No.3 1989/08/01(台風 12 号)

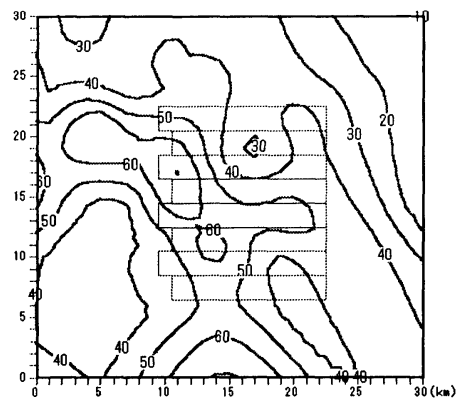

No.7 1981/07/22(集中豪雨)

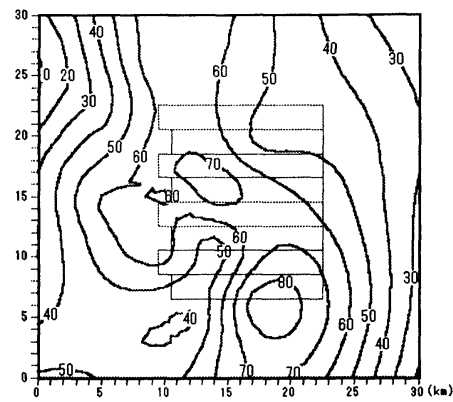

No.9 1987/07/24(集中豪雨)

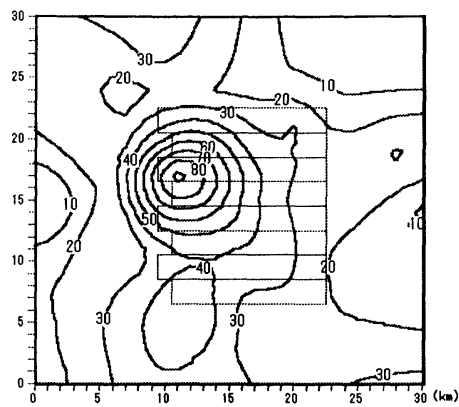

※図中数字は 60 分最大降雨量 $(\mathrm{mm} / \mathrm{hr})$, 細線はモデル流域位置 図-27 対象降雨の実績降雨分布 (60 分最大雨量)

(a) 改修前 No.3台風 〔46]

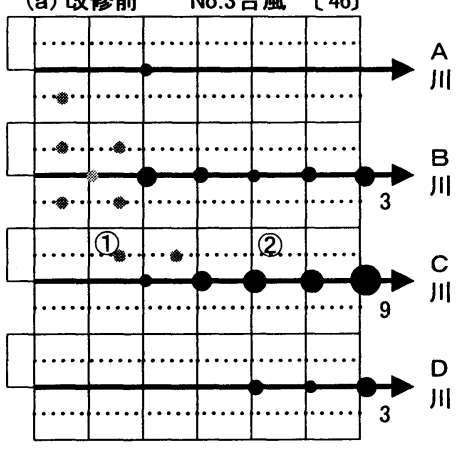

改修

(b) 改修後 No.3台風 [40]

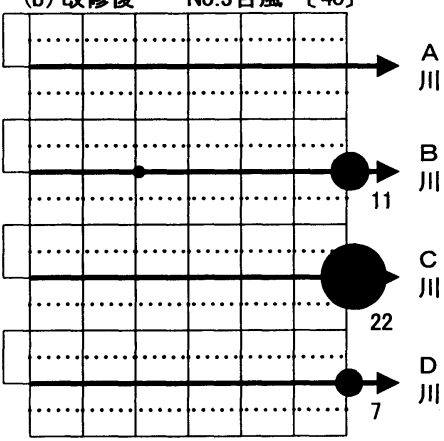

(下流端氾監容量 計 40 万 $\mathrm{m}^{3}$ )

No.3:1989/08/01（台風 12 号） (a) 改修前 No.7雷雨 [185]

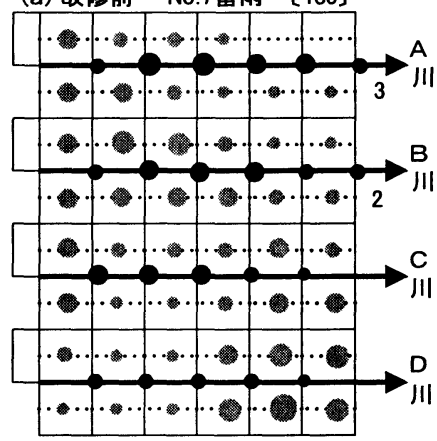

改修

(b)改修後 No.7雷雨 [128]

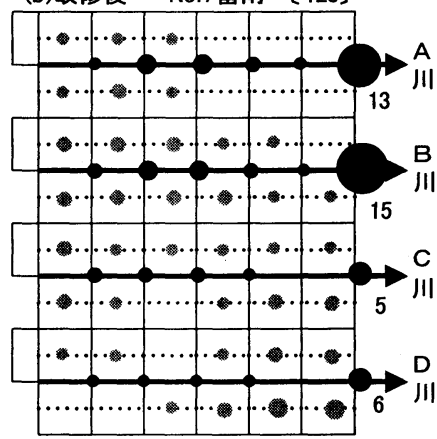

（下流端氾監容量 計39万m³)

No.7:1981/07/22 (集中豪雨) (a) 改修前 No.9雷雨 [72]

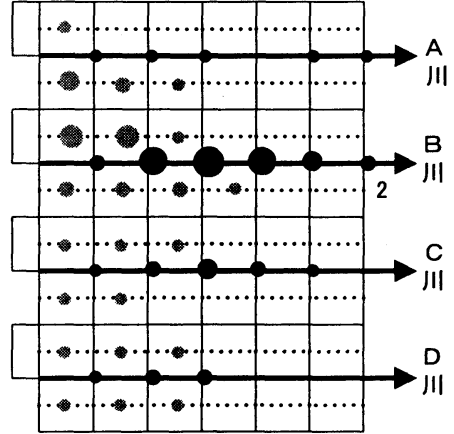

改修

(b) 改修後 No.9雷雨 [45]

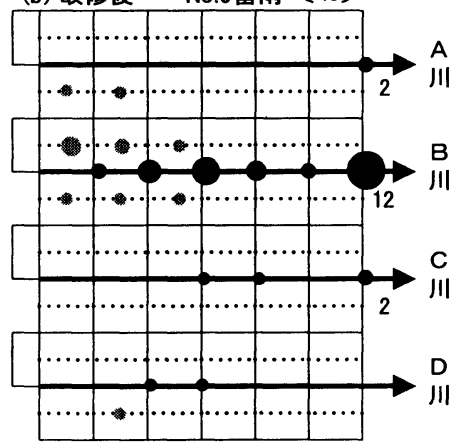

（下流端氾濫容量 計16万 $\mathrm{m}^{3}$ )

No.9:1987/07/24（集中豪雨）

※ O河道氾濫量 下水道氾濫量 図中数字は汇濫容量 $\left(\right.$ 万 $\left.\mathrm{m}^{3}\right)$, うち〔 書は, 総汇濫容量 図-28＼cjkstart治水対策の効果，影響 


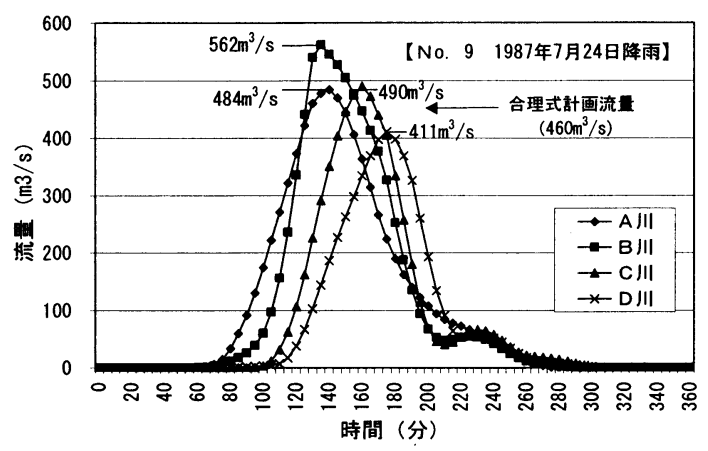

図-29 各河川の流出量の差

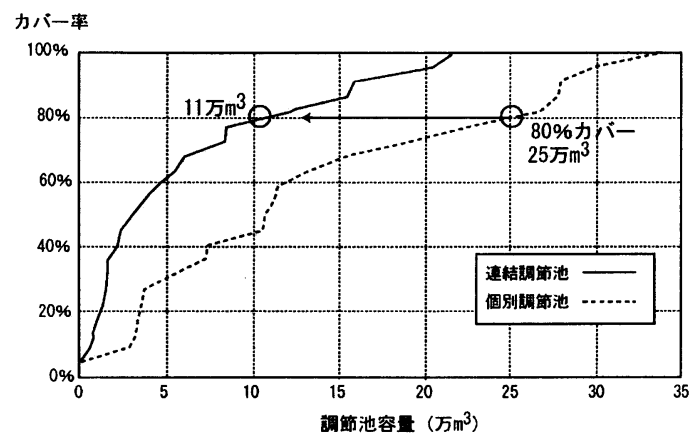

图一30 連絡式調節池の効果 ${ }^{26)}$

道が改修困難であった場合の汇濫量，いいかえれば，各河 川・各洪水での必要な洪水調節池容量を表現することとし ている. 図一26(a)に中央集中型降雨での結果を示す．中 央集中型降雨では，下水道，河道とも前項で検討したよう に，河川・下水道の各所での流下能力を上回り，河川，下 水道で汇濫している. 図一26(b)に下水道・河川を改修し た結果を示す．下水道・河川の氾濫は殆どなくなるが，河 川下流端での汇濫量が大きくなる．全体の河川・下水道の 汇濫ボリュームは改修前 78 万 $\mathrm{m}^{3}$ に比べて改修後は 63 万 $\mathrm{m}^{3}$ と約 2 割程度小さくなるものの, この河道・下水道の 改修は図一26(b)に示す様に下流河道の負担を増した結果 となる。

実績降雨の検討は, 図一27 に降雨の分布を示寸東京都東 部に発生した比較的規模の大きい3つの降雨を対象とした. 対象域は，およそ $3 \sim 5 \mathrm{~km}$ 間隔で 10 分毎の地上雨量記録 が得られており，これを $1 \mathrm{~km}$ メッシュに内挿することで 各小流域 $\left(2 \mathrm{~km}^{2}\right)$ の流域平均雨量を算定した. 図一28(a) に実績降雨による解析結果を示す。降雨の分布 (図一27) と比べて分かるようにその集中域で下水道が氾濫し，その 直下流側の河道が溢れる傾向にある. 図一26(a) 中の(1)に 示寸様に下水道で内水氾濫していながらその近傍河川で は殆ど汇濫しないのに比べ，図中(2)で示す下流河道で益水 しており，そこでは下水道は氾濫を起こしていない．

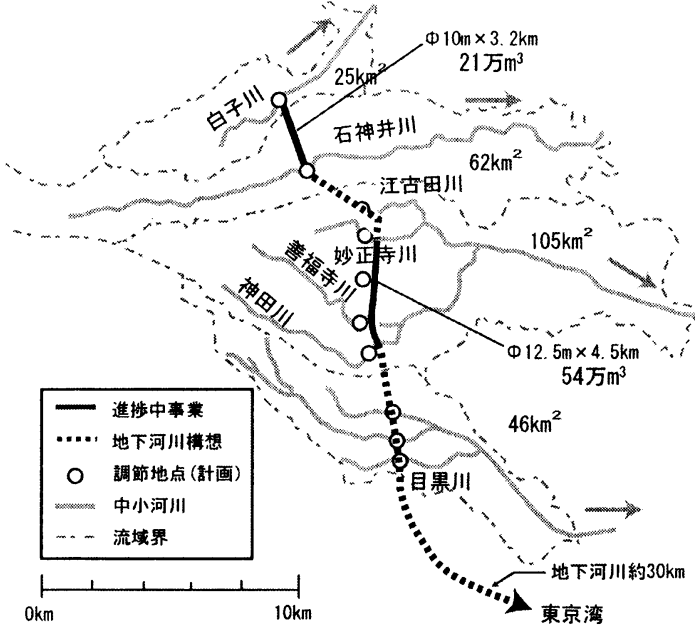

図一31 東京都地下河川構想 ${ }^{29}$

下水道，河川を改修した場合には，実績降雨（図一28(b)） でも中央集中型降雨の場合と同様で，No.3 の降雨では流 域内の氾濫がなくなり，下流への負担，汇濫が極めて大き くなる. No.7, No.9 の降雨では流域内の被害が若干低减 されるものの下流端での負担増が極めて大きくなる. 総汇 濫量は，先と同様に改修後に若干の低减が見られる．総氾 濫量は低減されても，河川・下水道の改修が，被害を下流 一移す結果となりうるので注意が必要である.この様に河 道・下水道の改修は下流河道の能力との整合や内水，外水 の汇濫の改修による変化，降雨地域分布などと合わせて考 えていく必要があることを示唆している.

\section{（2）流域を連絡する調節池の効果}

河道に調節池を設置する場合には，計画規模の降雨に対 して, 図一26(b) で示す様な下流端での氾濫を防ぐとして 各河川にその汇濫容量分の調節池 (各河川で 15 万 $\mathrm{m}^{3}$, 計 60 万 $\left.\mathrm{m}^{3}\right)$ を設置することになる. 図一26(b)で示すよう に実績降雨での下流端の氾濫量, つまり必要な調節池容量 は，降雨，河川毎に大きく異なり，1 洪水中では，調節池 を殆ど使わないで斉む河川と(例えばNo.3 のA川)，個別 の調節池（例えば 15 万 $\mathrm{m}^{3}$ ) でも氾濫が生じる河川 (No.3 でのC川）とが必ず混在することが分かる. 図一29にNo.9 の集中豪雨に対する $\mathrm{A} \sim \mathrm{D}$ までの各河川下流端での八イ ドログラフを示寸. 各河川での流量は大きく異なっており, 例えば合理式での計画流量 $460 \mathrm{~m}^{3} / \mathrm{s}$ を超える量を必要な 調節流量とすれば，この流量はB川の $102 \mathrm{~m}^{3} / \mathrm{s} \quad\left(562 \mathrm{~m}^{3} / \mathrm{s}\right.$ $-460 \mathrm{~m}^{3} / \mathrm{s}$ ) に比べD川では全く調節を必要としない結果 になる.この点から，河川毎に通常計画される 15 万 $\mathrm{m}^{3}$ の 4 箇所の個別な調節池を設置するよりも, これらを連絡 する様な調節池とすることで，降雨，洪水の地域分布に柔 
軟に対処出来る調節池となることは想像に難くない．

流域一律の中央集中型降雨外力を想定して, 個別河川で の調節池を計画するとすれば, 図一26(b) に示すように 15 $\times 4=60$ 万 $\mathrm{m}^{3}$ が必要とされるが，図一28(b)に示す No.3 の降雨で $\mathrm{C川では} 22$ 万 $\mathrm{m}^{3}$ 必要であり, この 15 万 $\mathrm{m}^{3}$ の 個別調節池では容量が足らずに汇濫する.これに比べて対 象とした 3 降雨全てに対しても, 40 万 $\mathrm{m}^{3}$ の連結した調節 池があれば対応出来る. また洪水毎での調節池の空容量も 合計として小さくなり効率的である.

河川・下水道流域での連絡調節池の効果の検討として, 著者ら ${ }^{26)}$ は，実績の降雨群（実際に東京都区部に被害の 見られた 29 降雨) に対して, 図一30に示寸様に $80 \%$ の力 バ一率を得る場合には，個別に調節池を設置するよりも連 絡式の調節池とすることでその約 $45 \%$ の調節池容量で対 応出来る試算例を示している. また下水道管渠をループ型 の貯留管とすることで, 偏在性降雨に対して効果的である という報告 ${ }^{27)}$ や，下水道施設のネットワークの効果を検 討した事例 ${ }^{28)}$ もある. 連絡式の調節施設の実現性という 観点では, 図一-31 に示寸様に東京都区部で 4 水系 10 ヶ所 からの洪水調節を図る地下河川の構想 ${ }^{29)}$ もなされており, 現在事業進渉中で部分的には供用開始されていることか らも, 本検討でイメージする連絡式調節池は具体的に実現 される可能性がある規模である事に加え, その様々な降雨 分布に対応出来る効率的な運用が期待出来る.

市街化された都市域での地下河川, 地下調節池等の治水 施設については, 合理式における流域一律降雨に対する検 討での範囲を超えて, 地域的な降雨の時空間偏差を有効活 用し，流域を連絡する調節池による対策やこれらを含めた 河川, 下水道のネットワーク化が有効で, その効果や治水 計画への反映, 積極的活用が望まれる.

\section{5. まとめ}

本章では 2 4 章での都市中小河川や下水道の降雨, 流 出, 氾濫特性の整理, 合理式と合成合理式の差異及び治水 対策の検討を踏まえ，台地部既成市街地における中小河 川・下水道の連携した治水計画を行う方法と留意点（図一 32）について著者らの考えを述べる. さらに今後の技術的 課題についてまとめる.

（1）降雨要因，降雨の時空間分布を考慮した外力の設定 流出 - 氾濫現象は, 台風や雷雨等の降雨要因や短時間降 雨の時空間分布により様々となる.

治水計画, 治水対策の検討を行う降雨外力の設定は, 河 川・下水道で同一の, 実態として起きうる様々な複数の降 雨外力を群として対象とすることが重要である.

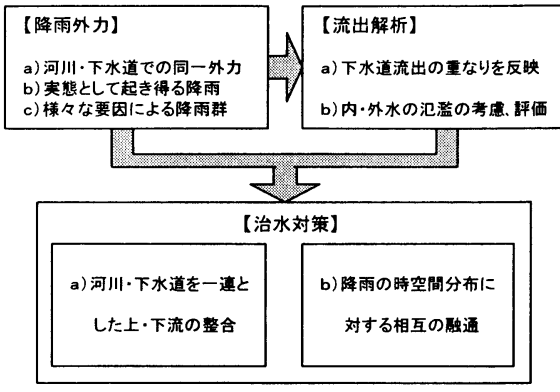

図-32 河川・下水道の連携した治水計画の立て方

\section{a) 河川・下水道で同一の外力であること}

河川と下水道においては, 流出・汇濫現象が相互に影響 し合うので，各々の到達時間による対象外力を対象とす るのでなく，河川・下水道で同一外力が発生した場合に どちらにどの様な流出・氾濫被害が発生するか, また被 害の総合的な評価が必要であり, 同時に生起し得る河 川・下水道での同一の外力の設定が必要である.

\section{b）実態として起きうる外力を対象とすること}

降雨の地域分布, 時間分布は一様ではないので, また 降雨の時空間分布が流出に与える影響が大きいので, 流 域一律の中央集中型降雨の様な架空の降雨でなく, 実際 に起こり得る降雨要因による特性も加味した降雨の時空 間分布を主に，設定することが重要である.

c）様々な降雨要因による複数の降雨群を対象とすること

台風性や雷雨性などの時空間分布を異にする降雨外力 に対して, 総合的に被害を最小限にする必要があるので, 単一の降雨外力でなく, 実際に起きうる様々な降雨要因や 地域分布をもった降雨群の設定と, その群全体としての被 害を最小とする最適な治水対策を検討する必要がある.

\section{（2）河川 - 下水道を一体 - 一連とする流出解析手法}

台地部の都市中小河川・下水道での流出は，短時間降雨 と線形的関係にある. 下水道の流出は, 河川のピーク流量 に大きく影響し, 河川流量は多くの小さな下水道の流出量 の重なり方に支配されている. このため, 都市域の河川・ 下水道の治水計画を行う検討モデルは，これまでの合理式 に代えて降雨の時空間分布や下水道流出量の重ね合わせ を考慮出来ること, 内・外水の汇濫量が流出に及ぼす影響 も考慮出来るモデルであることが必要である.

\section{a）下水道の流出量の重ね合わせが解析出来ること}

河川流量は下水道の流出の重なり方や降雨の時間分布, 地域分布に大きく影響するので，例えば，下水道の管理区 分界である $2 \mathrm{~km}^{2}$ 以上となる下水道幹線や中小河川の流域 は, 合理式にかえて合成合理式等の，降雨外力の時空間分 布や下水道の流出量の重ね合わせが細かに再現出来る流 出解析モデルを用いることが必要である. 
b) 内·外水の氾監量 総体的な浸水被害か婊現出来ること

河川，下水道での内・外水汇濫が流出量に影響し，また 同一外力に対する総合的な被害を評価する必要があるの で, 下水道・河川での内・外水汇濫や流域, 河川・下水道 での貯留施設の効果が考慮・再現出来るモデルとする必要 がある.

\section{（3）河川・下水道での整合・連擭した治水対策}

河川・下水道での連携した治水対策は，全体として最も 効率的な治水対策の組合せ, 様々な降雨に対する柔軟な連 携・融通を考えていく必要がある.

\section{a）河川・下水道の改修の効果 · 相互影響の考慮}

下水道, 河道の改修は, 河道下流への負担を大きくする こととなり，その改修規模，氾濫被害との関係，その対策 の整合性に配慮することが重要となる. 下水道・河川の改 修や調節池の建設は，相対的に汇濫被害を上流から下流へ 移相させたり，河道，調節池に余分な余裕を生む場合があ るなど瓦いに影響し合うので, 整合のとれた治水計画を相 互に調整，連携して設定することが肝要である.

\section{b）降雨の地域分布・時間分布への融通}

実績降雨分布に対する流出量は, 河川毎, 下水道毎に地 域偏差が大きく, 流域を連絡して降雨・洪水の地域分布・ 時間分布に柔軟に対処する連絡式調節池や，河川・下水の ネットワークなどが，効果的・効率的な治水対策となる. この点で河川・下水道で一体となった全体の施設を有效活 用する治水計画が重要である. 一定の計画外力に基づく, 河川・下水の分担量をきめることではなく，様々な時空間 分布を持つ洪水に対して，より効率的かつ柔軟に施設能力 を融通しあえる治水対策の設定, 工夫が重要であると考え る.

\section{（4）今後の技術的課題}

\section{a) 狭域・短時間雨量の時空間分布特性の把握と計画への 反映}

現在の合理式に用いられている降雨強度曲線は, 代表観 測所一地点での降雨量の統計処理により求められており 流域の広がりを持つなかでの地域偏差は考慮されていな い. また, 流域面積が広がる程流域平均降雨強度は弱まる ため, その生起確率も地点でのものと違ってくる. さらに, 地点での継続時間毎の年最大雨量を対象としているため, 台風, 雷雨等の要因, 様相の異なる降雨を併せて継続時間 と雨量強度の関係を作成しているため, 到達時間によって は降雨発生要因の異なる降雨を合わせて用いていること が考えられる. 都市域の中小河川・下水道においては, 合 理式で考慮されない降雨の時空間分布や降雨要因による 特性の違いが流出・汇濫現象に大きく効いてくるので, ま ず外力としての降雨現象，特に短時間・狭域での降雨の時 空間分布特性, DAD特性等の把握に資するデータの蓄積
と解析, 計画への反映が重要な課題であると考えられる. また様々な降雨の時空間分布に, 柔軟かつ効率的に, 対応 するための河川・下水道のネットワーク的な治水対策を考 慮していくうえでも，その中小河川，下水道のスケールで の外力の時空間分布の特性を把握することは極めて重要 である.

\section{b）下水道の流出実態の把握と治水計画への反映}

河川の治水計画を行う場合には，下水道の整備状況，流 出の実態・特性を十分に把握し，その河川での重なり方に 対応する計画・対策及び段階的な整備計画の立案が必要で ある. 一方で下水道の計画では, 河川の能力, 計画を十分 に把握し，それに対応する適切な治水対策を行い河川への 内水汇濫も含めた流出のインパクトを知らしめることが 必要である. このように河川と下水道は, 連続した一体の 都市排水システムであり，効率的な整合のとれた治水施設 整備・治水計画を図っていく必要があるので, 特に下水道 の流出・氾濫の実態, 特性の把握と治水計画の反映が重要 な課題である.

c）下水道・中小河川での水文データの実態観測体制の強化 中小河川・下水道では, 今までに細かな流出実態や，降 雨の時空間的に密な分布などの観測が困難であったが，今 後は, レーダ雨量計や最新の観測技術を駆使して, 河川・ 下水道で連携した効率的な水位, 流量, 降雨, 汇濫の実態 観測の体制を整備, 強化していくことが重要である.

これまでの下水道, 河川で各々の計画規模に対する一定 の洪水に対して，排水量を各々に，また「分担」し個別に 進められてきた治水対策の考え方から，今後は整備途上の 段階も含めて河川・下水道相互の影響への配慮, 様々な降 雨外力に対する柔軟な対応と融通, 総合的な被害の評価と 効率的な対策などの「連携」が重要な課題である. 今後の 河川・下水道の治水対策はこの「分担」から「連携」への 転換が重要であると考える.

謝辞 : 本検討のモデル流域に対してのケーススタディを行 うに当たり東京都建設局河川部計画課に実績雨量データ や流域・計画等の資料の提供を頂きました. ここに記し謝 意を表します。

\section{参考文献}

1）建設省河川局治水課・河川環境課監修: 河川改修事業関係例規 集, 社団法人日本河川協会, 例えば平成 8 年度版, pp.675-676, 1996.

2）中小河川計画検討会編集 : 中小河川計画の手引き (案)，(財) 国土開発技術研究センター発行, pp.3-16, 1999.

3）建設省都市局下水道部監修，社団法人日本下水道協会：下水道 施設計画・設計指針と解説-1994 年度版一前編，pp. 59-67, 1994. 
4）財団法人下水道新技術推進機構 : 流出解析モデル利活用マニ ユアル（雨水対策における流出解析モデルの運用手引き）, 1999.3.

5）肱岡靖明, 古米弘明, 市川新 : 下水道台帳データベースと細 密数値情報を利用した分布型モデルによる都市雨水流出解 析, 下水道協会誌, Vol.38, No.469, pp.79-89, 2001.

6）建設省河川局監修，社団法人日本河川協会編 : 改訂建設省砂 防技術基淮 (案) 計画編, pp.19-20, 同調査編, pp.149-150, 山海堂, 1985 .

7）山口高志，松原重昭，山守隆 : 都市流出解析一降雨損失機構 の検討一，土木技術資料,Vol.13，No.10，pp.11-15， 1971.

8）山口高志，松原重昭，山守隆 : 都市における降雨流出調查第 2 報一修正RRL法による流出推定一, 土木技術資料, Vol.14, No.11, pp.34-39, 1972.

9）山口高志，松原重昭，山守隆 : 都市における降雨流出調查第 3 報一修正 RRL 法の実用化化伴亏諸問題一, 土木技術資料, Vol.15, No.7, pp.37-42, p.46, 1973.

10）橋本建, 長谷川正: 土地利用変化を評価する流出モデル，土 木技術資料, Vol.19, No.5, pp.11-16, 1977.

11）和泉清, 吉川秀夫: 下水道整備が洪水流出現象に及ぼす影響, 土木学会論文集，第 399 号/II-10, pp.113-120, 1988.

12）福岡捷二, 谷岡康, 高本正彦: 都市域中小河川流域における 雨量観測所の密度が面積雨量精度に与える影響, 水工学論文 集, 第 37 巻, pp.27-32, 1993.

13）谷岡康, 福岡捷二, 岩永勉, 傳雲飛 : 都市中小河川流域規模 を対象とした短時間雨量の変動特性と短時間降雨予測の試み, 水工学論文集，第 39 巻，pp.56-60, 1995.

14）谷岡康, 福岡捷二, 傳雲飛: 都市中小河川規模を対象とした 地上雨量計による短時間雨量の変動予測, 水工学論文集, 第 40 巻, pp.273-278, 1996.

15）伊藤繁之, 福剛捷二, 谷岡康: 都市中小河川流域における雷 雨性降雨の時空間変動特性, 第 51 回土木学会年次学術講演 会講演概要集第 2 部, pp.768-769, 1996.

16）谷岡康, 福岡捷二, 岩永勉, 北川明 : 都市域中小河川におけ る洪水位と雨量の直接的関係を用いた洪水解析, 水工学論文 集, 第 38 巻, pp.69-74, 1994.
17）谷口将俊, 福岡捷二, 谷岡康: 都市中小河川の洪水実態とその 解析, 第 51 回土木学会年次学術講演会講演概要集, 第 2 部, pp.688-689, 1996.

18）福岡捷二, 川重光正, 谷岡康; 都市中小河川における降雨と 流出, 第 47 回平成 7 年度士木学会中国支部研究発表会概要 集, 1995.

19）谷岡康 : 都市中小河川流域における降雨と洪水流出の特性に 関する研究，広島大学学位論文，pp.22-26，1998.3

20）谷岡康, 福岡捷二, 谷口将俊, 小山幸也: 都市中小河川の洪 水流出特性，土木学会論文集，No.586／II·42，pp.1-12, 1998.2

21）吉野文雄 : 合理式による洪水流量の算定についての提案，第 27 回建設省技術研究会報告, pp.581-586, 1975 .

22）谷岡康，福岡捷二，伊藤繁之，小山幸也，傅雲飛 : 都市中小 河川流域規模を対象とした短時間雨量の特性，土木学会論文 集，第579号／II-41，pp.29-45，1997.11

23) Viessman, W., Jr. and Lewis, G.L. : Intoduction to Hydrology, Fourth Edition, Harper Collins College Publishers, p.318, 1996.

24）東京都建設局河川部計画課 : ' 85 東京の中小河川，pp.22-24, 1985.

25）都市型水害対策検討委員会 : 委員会検討資料，2002.6

26）谷岡康, 福剛捷二, 高橋康夫: 都市中小河川における連絡式 調節池の効果, 士木学会水工学論文集, 第 43 巻, pp.163-168, . 1999.

27）佐伯謹吾 : 効率的な雨水整備に関する一試案,下水道協会誌, Vol.36, No.440, pp.9-18, 1999.6

28）伊藤尃 : 貯留とネットワークによる効率的な浸水対策，流域 管理 2001 講演要旨集, ヨーロッ八冰協会・米国水環境連盟・ 社団法人日本下水道協会, pp.12-14，2001.7

29）東京都地下河川構想検討会事務局 : 地下河川（UNDER GROUND RIVER)，東京都パンフレット，1991.8

(2002. 7. 30 受付)

\title{
FLOOD CONTROL PROJECTS THROUGH COORDINATION BETWEEN RIVERS AND SEWERS IN URBAN AREAS
} -PROJECTS FOR PLATEAU BUILT-UPAREAS-

\author{
Yasushi TANIOKA and Shoji FUKUOKA
}

\begin{abstract}
Flood control systems for urban areas in which outflows of rivers and sewers are correlated require crisis-management measures to be taken in advance to minimize the entire damage of excess floods. However, flood control projects through coordination between rivers and sewers must be given highest priority and must be considered immediately to cope with urban flood disasters, which occur almost every year. This paper deals with catchment areas of small sized rivers and sewers in plateau urban areas where sewages are naturally drained to rivers. It will present problems of the flood control measures being developed for each flood control project that is based on a rational method commonly used for sewers and small to medium sized rivers, by examining the actual conditions of rainfalls and characteristics of outflows and implementing concrete and practical case studies. It will then present a method for implementing flood control projects through coordination between rivers and sewers based on a composite rational method and clarify problems to be addressed in the future.
\end{abstract}

